\title{
Additions to the Myxomycetes of Singapore ${ }^{1}$
}

\author{
Wayne C. Rosing, ${ }^{2,6}$ David W. Mitchell, ${ }^{3}$ Gabriel Moreno, ${ }^{4}$ and Steven L. Stephenson ${ }^{5}$
}

\begin{abstract}
Much of Southeast Asia remains understudied for myxomycetes (plasmodial slime molds or myxogastrids). This survey of myxomycetes was carried out at 12 study sites throughout Singapore during March 2009. Sporocarps that developed in moist-chamber cultures of bark, forest floor litter, and aerial litter were used to supplement field collections. In addition, a series of samples of various types of plant litter collected from one other study site during the summer of 2004 was processed for myxomycetes. Collectively, these efforts yielded 76 species of myxomycetes in 26 genera. Thirty-six species are new records for Singapore. The latter includes two previously unpublished records along with one collection of Didymium and one collection of Trichia that could not be assigned to any known species.
\end{abstract}

IN FOREST ECOSYSTEMS, most myxomycetes (plasmodial slime molds or myxogastrids) produce spore-containing sporocarps on woody debris and leaf litter. Other species occupy microhabitats such as the bark surface of living trees. Sporocarps of these myxomycetes are usually too minute to be detected in the field but can be recovered with the use of the moist-chamber technique first described by Gilbert and Martin (1933).

Published reports on the myxomycetes of Malaysia and Singapore (Chipp 1921, Sanderson 1922, Emoto 1931a, Lister 1931, Nawawi 1973) as well as a majority of the reports on the myxomycetes of other Southeast Asian countries considered only species that produce sporocarps large enough to be detected in the field. Based exclusively on speci-

\footnotetext{
${ }^{1}$ Manuscript accepted 26 October 2010.

${ }^{2}$ Department of Biology, Middle Tennessee State University, Murfreesboro, Tennessee 37132.

${ }^{3}$ Walton Cottage, Upper Hartfield, East Sussex, England TN7 4AN, United Kingdom.

${ }^{4}$ Departamento de Biología Vegetal, Universidad de Alcalá, 28871 Alcalá de Henares, Madrid, Spain.

${ }^{5}$ Department of Biological Sciences, University of Arkansas, Fayetteville, Arkansas 72701.

${ }^{6}$ Corresponding author (e-mail: wrosing@mtsu.edu).
}

Pacific Science (2011), vol. 65, no. 3:391-400

doi: $10.2984 / 65.3 .391$

(C) 2011 by University of Hawai'i Press

All rights reserved mens obtained from moist-chambered bark samples, Rosing (2009) reported 17 new records for Singapore, mostly species that produce minute sporocarps. The records reported herein include field collections made by W.C.R. while a Research Fellow at the Singapore Botanic Gardens along with a number of additional records based on specimens obtained in moist-chamber cultures, with some of the latter recorded from samples of various types of plant debris collected during June and July of 2004 and processed at the University of Arkansas.

\section{MATERIALS AND METHODS}

At each locality (Table 1), field collections of sporocarps were made as the opportunity allowed. Samples of ground litter, aerial litter (dead leaves and inflorescences trapped in shrubs, etc.), and bark were collected at each locality. Bark samples (consisting of five to eight pieces of $2-5 \mathrm{~cm}$ size) were collected from living trees at a trunk height of approximately $1.5 \mathrm{~m}$. All samples were air-dried and then placed in paper packets for later moistchamber processing.

Each moist chamber consisted of pieces of a particular substrate on filter paper in a disposable plastic petri dish (9 $\mathrm{cm}$ diam.). Substrates were flooded with sterile distilled water adjusted to $\mathrm{pH} 7.0$ with $\mathrm{KOH}$. Because substrate $\mathrm{pH}$ sometimes affects the abundance 
TABLE 1

Singapore Localities from Which Specimens of Myxomycetes and Samples of Bark and Litter Were Obtained

\begin{tabular}{lll}
\hline \hline Localities & \multicolumn{1}{c}{ Description } & \multicolumn{1}{c}{ GPS Coordinates } \\
\hline Locality 1 & Singapore Botanic Gardens & $1^{\circ} 18^{\prime} 37^{\prime \prime} \mathrm{N}, 103^{\circ} 48^{\prime} 53^{\prime \prime} \mathrm{E}$ \\
Locality 2 & Mandai Tree Sampling Plot MS 3 & $1^{\circ} 24^{\prime} 51^{\prime \prime} \mathrm{N}, 103^{\circ} 48^{\prime} 01^{\prime \prime} \mathrm{E}$ \\
Locality 3 & Bukit Timah Nature Reserve & $1^{\circ} 21^{\prime} 08^{\prime \prime} \mathrm{N}, 103^{\circ} 46^{\prime} 36^{\prime \prime} \mathrm{E}$ \\
Locality 4 & MacRitchie Reservoir Forest Reserve & $1^{\circ} 21^{\prime} 34^{\prime \prime} \mathrm{N}, 103^{\circ} 48^{\prime} 39^{\prime \prime} \mathrm{E}$ \\
Locality 5 & Labrador Park & $1^{\circ} 16^{\prime} 00^{\prime \prime} \mathrm{N}, 103^{\circ} 48^{\prime} 08^{\prime \prime} \mathrm{E}$ \\
Locality 6 & Kent Ridge Park & $1^{\circ} 17^{\prime} 08^{\prime \prime} \mathrm{N}, 103^{\circ} 47^{\prime} 16^{\prime \prime} \mathrm{E}$ \\
Locality 7 & Kent Ridge above King Edward VII Hall & $1^{\circ} 17^{\prime} 33^{\prime \prime} \mathrm{N}, 103^{\circ} 46^{\prime} 51^{\prime \prime} \mathrm{E}$ \\
Locality 8 & Sentosa Island & $1^{\circ} 14^{\prime} 58^{\prime \prime} \mathrm{N}, 103^{\circ} 49^{\prime} 43^{\prime \prime} \mathrm{E}$ \\
Locality 9 & Palau Ubin & $1^{\circ} 24^{\prime} 32^{\prime \prime} \mathrm{N}, 103^{\circ} 57^{\prime} 55^{\prime \prime} \mathrm{E}$ \\
Locality 10 & St. John's Island & $1^{\circ} 13^{\prime} 07^{\prime \prime} \mathrm{N}, 103^{\circ} 50^{\prime} 35^{\prime \prime} \mathrm{E}$ \\
Locality 11 & $1^{\circ} 13^{\prime} 25^{\prime \prime} \mathrm{N}, 103^{\circ} 51^{\prime} 35^{\prime \prime} \mathrm{E}$ \\
Locality 12 & Kusu Island & $1^{\circ} 20^{\prime} 33^{\prime \prime} \mathrm{N}, 103^{\circ} 40^{\prime} 48^{\prime \prime} \mathrm{E}$ \\
Locality 13 & Nanyang Technological University & $1^{\circ} 08^{\prime} 36^{\prime \prime} \mathrm{N}, 103^{\circ} 46^{\prime} 48^{\prime \prime} \mathrm{E}$ \\
\hline
\end{tabular}

Note: All collections and samples from Localities 1-12 were obtained by W.C.R. during the first 3 weeks of March 2009. These samples were processed at Middle Tennessee State University. Samples from Locality 13 were collected in June and July of 2004 and sent to the University of Arkansas for processing.

and distribution of myxomycetes (Stephenson 1989, Wrigley de Basanta 2004), excess water remaining after $24 \mathrm{hr}$ was poured into clean plastic beakers where $\mathrm{pH}$ was determined using a pH meter (Orion model 210A) and low-maintenance electrode. Moist chambers were incubated at room temperature (22$25^{\circ} \mathrm{C}$ ), exposed to diffuse daylight, and examined daily for a period of 5 weeks, or longer if the bark was still producing sporocarps or plasmodia. Small amounts of water were periodically added to each culture to maintain moist conditions. If sporocarps of the same species of myxomycete appeared more than once in the same culture of moist-chambered substrate, they were considered to be a single collection. However, if sporocarps of the same species appeared in different moist chambers of the same substrate, they were considered to represent different collections.

Once sporocarps were mature, they were removed from the moist chambers along with part of the substrate upon which they developed. Once air-dried, specimens were glued into herbarium-quality boxes (Middle Tennessee State University) or small pasteboard boxes (University of Arkansas) for permanent storage. Identifications were made using keys by Martin and Alexopoulos (1969) and Mitchell (2004).
Nomenclature of myxomycetes essentially follows Lado (2005) and uses the conserved names of a number of genera (Lado et al. 2005) approved by the Committee for Fungi (Gams 2005) of the International Association for Plant Taxonomy. The International Plant Name Index (2008) is followed for the plant taxa from which bark samples were collected. Representative specimens have been deposited in the herbarium of the Singapore Botanic Gardens (SING). Collection numbers are those of the first author (WCR) except specimens collected by the fourth author (SLS), which are indicated with his initials. The latter are deposited in the mycological herbarium of the University of Arkansas (UARK).

\section{RESULTS}

\section{Annotated List of Species}

Field collections $(\mathrm{F})$ and collections obtained from moist-chamber cultures (MC) yielded a total of 76 species of myxomycetes, including 36 new records for Singapore. The latter include two previously unpublished records along with one collection of Didymium and one collection of Trichia that could not be assigned to any known species. In the list that follows, myxomycete taxa are arranged alpha- 


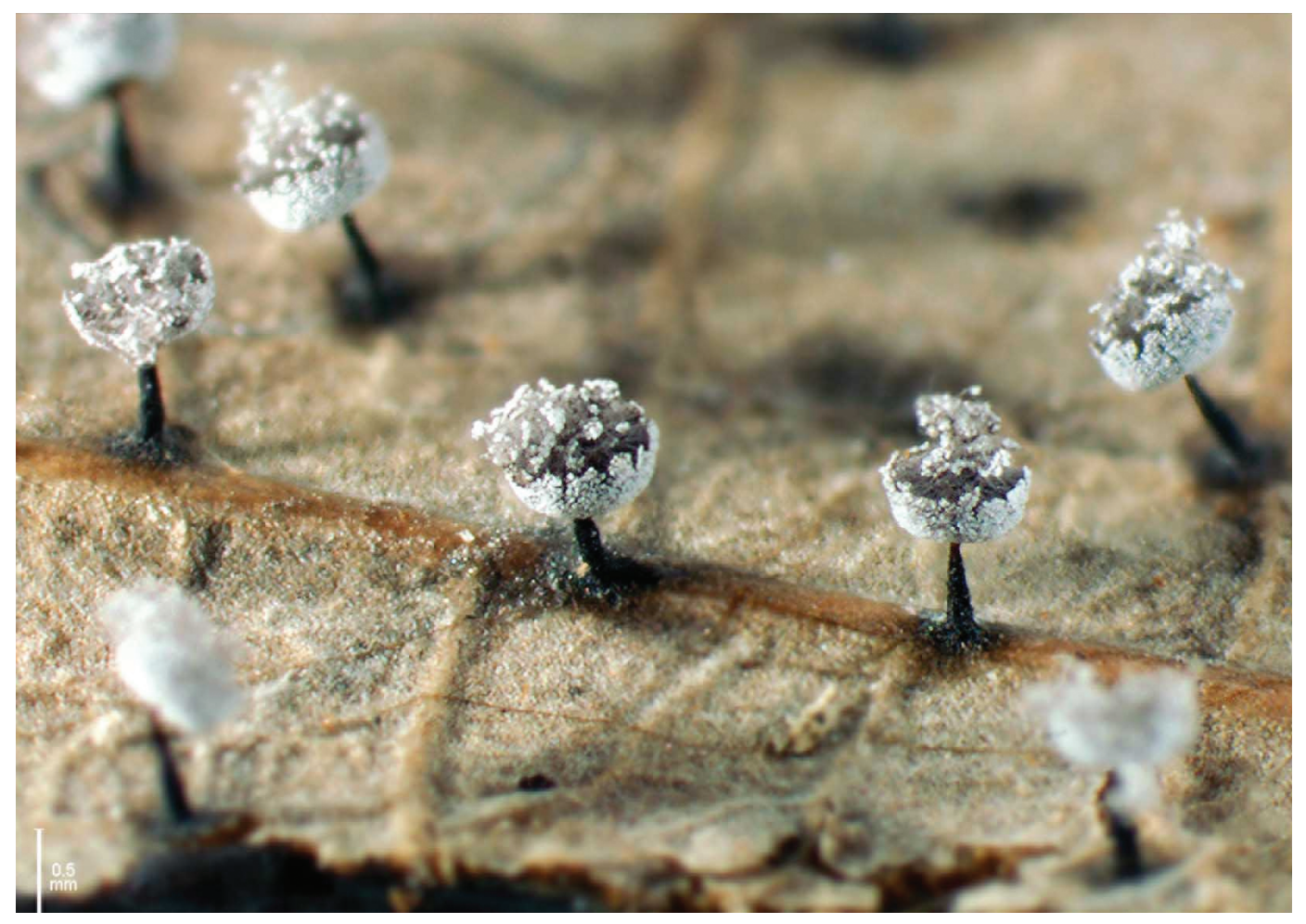

Plate i. Sporocarps of Didymium sp.

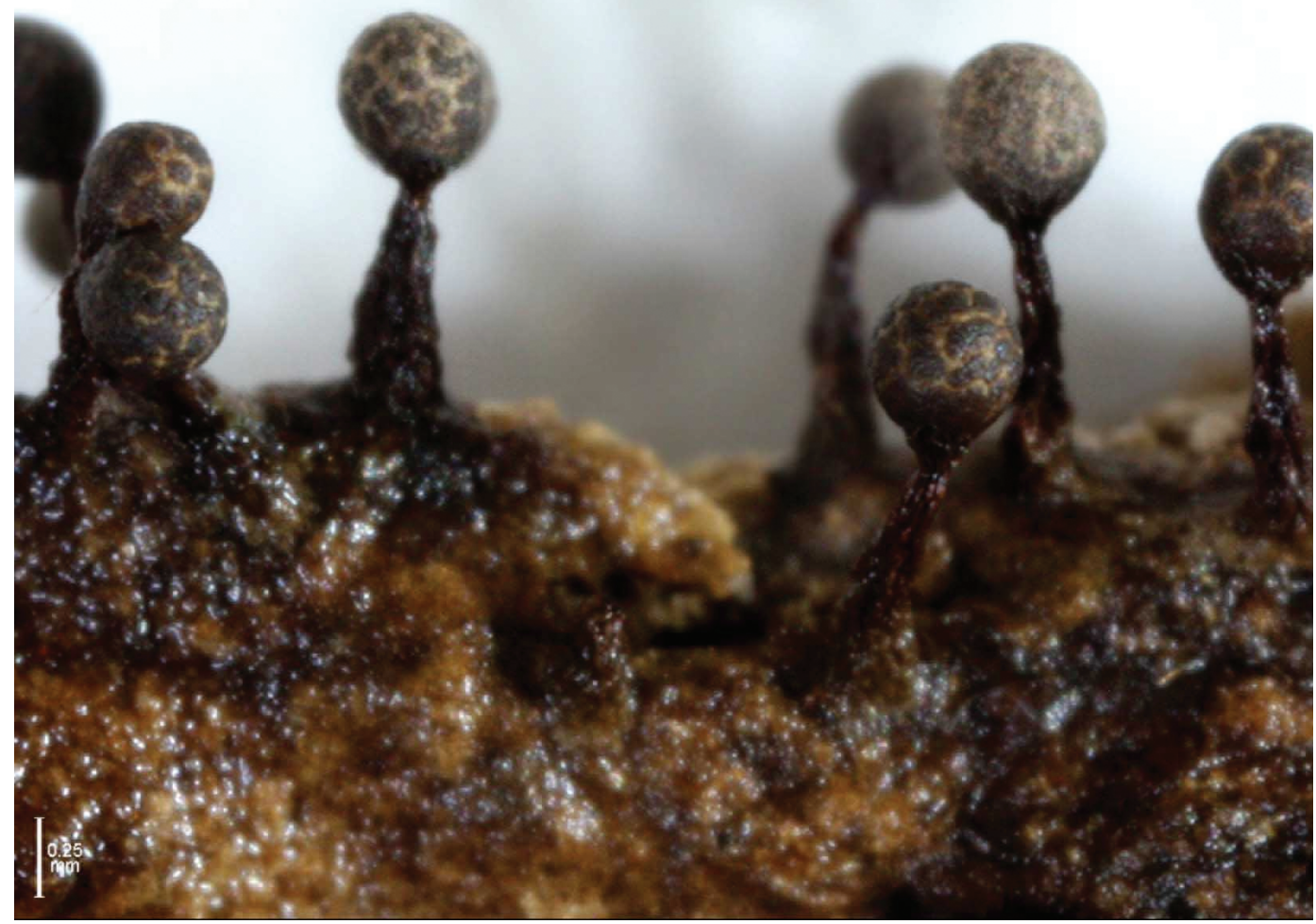

Plate i . Sporocarps of Trichia sp. 
betically by genus and then species epithet. An asterisk $\left(^{*}\right)$ indicates a species previously not reported in print as occurring in Singapore. For collections obtained from moistchamber cultures, the $\mathrm{pH}$ of the substrate(s) is given in brackets.

*Arcyria afroalpina Rammeloo [6.9]

Locality 13: MC SLS23,694.

New record for Singapore but reported from Thailand by Tran et al. (2008).

Arcyria cinerea (Bull.) Pers. [4.0-5.6]

Locality 1: F 9962; MC 9910, 9911, 9953, and 10,015. Locality 2: MC 9918, 9940, and 10,019. Locality 3: MC 9961 and 10,018. Locality 4: MC 9981. Locality 5: MC 9944. Locality 6: F 10,016. Locality 8: MC 9964. Locality 9: F 9963 and 10,017. Locality 11: MC 10,014.

First reported from Singapore by Emoto (1931a).

Arcyria denudata (L.) Wettst. [4.8]

Locality 1: F 9956 and 10,000; MC 9896. Locality 3: F 9957. Locality 4: F 9946. Locality 9: F 10,001, 10,033, and 10,047. Locality 12: F 10,002 .

First reported from Singapore by Chipp (1921).

* Arcyria insignis Kalchbr. \& Cooke

Locality 1: F 9907 and 10,054.

New record for Singapore but reported from peninsular Malaysia by Sanderson (1922).

\section{*Arcyria magna Rex}

Locality 3: F 9917. Locality 4: F 9850.

New record for Singapore.

Arcyria minuta Buchet [5.1]

Locality 9: MC 10,053.

First reported from Singapore by Rosing (2009).

Arcyria nutans (Bull.) Grev. [= Arcyria obvelata (Oeder) Onsberg]

Locality 9: F 9879. Locality 12: F 9878.

First reported from Singapore by Chipp (1921).
Arcyria pomiformis (Leers) Rostaf. [3.9-5.3]

Locality 3: MC 9942. Locality 5: MC 9927. Locality 8: MC 10,055. Locality 11: MC 9928.

First reported from Singapore by Rosing (2009).

Ceratiomyxa fruticulosa (O. F. Mull.) T. Macbr. Locality 1: F 9996. Locality 3: F 9986. Locality 4: F 10,030. Locality 9: F 9923.

First reported from Singapore by Chipp (1921).

Although traditionally included in myxomycete surveys, many now accept that Ceratiomyxa should be classified as a member of the Subclass Protostelia.

Clastoderma debaryanum A. Blytt [4.2-7.2]

Locality 1: MC 9910, 9919, 9941, 9966, 9967, 9968, 9970, 9978, 10,010, 10,040, and 10,051. Locality 2: MC 9925. Locality 4: MC 10,043. Locality 5: MC 9937 and 10,021. Locality 8: MC 9971 and 10,058. Locality 10: MC 9979.

First reported from Singapore by Emoto (1931a).

Collaria arcyrionema (Rostaf.) Nann.-Bremek. ex Lado

Locality 9: F 9879.

First reported (as Lamproderma arcyrionema Rost.) from Singapore by Emoto (1931a).

Comatricha elegans (Racib.) G. Lister [4.0-5.1] Locality 1: F 9920; MC 10,052. Locality 2: MC 9973. Locality 5: MC 10,011, 10,035, and 10,045. Locality 7: MC 10,048. Locality 9: MC 9995.

First reported from Singapore by Emoto (1931a).

${ }^{*}$ Comatricha cf. laxa Rostaf. [4.0-4.5]

Locality 13: MC SLS23,706, SLS23,707.

New record for Singapore but reported from peninsular Malaysia by Sanderson (1922) and more recently from Thailand by Tran et al. (2006).

Comatricha pseudonigra G. Moreno, W. C. Rosing, D. W. Mitch. \& S. L. Stephenson [4.3] 
Locality 4: MC 10,063 (microscope slide only).

A single sporocarp developed on moistchambered bark of Streblus elongatus (Miq.) Corner ( $\mathrm{pH} 4.3$ ) collected by W.C.R. from the MacRitchie Reservoir Forest Reserve, Singapore, on 12 March 2009. As reported here, bark of $S$. elongatus is the first identified substrate for this species, first described from the moist-chambered bark of an unidentified tree ( $\mathrm{pH}$ 3.8), Mitchell River National Park, Victoria, Australia (Moreno et al. 2007).

First reported from Singapore on moistchambered bark of an unidentified tree $(\mathrm{pH}$ 3.7) by Rosing (2009).

Comatricha pulchella (C. Bab.) Rostaf. [5.5-5.7] Locality 1: MC 10,062. Locality 5: F 9904 and 9905. Locality 11: MC 9898.

First reported from Singapore by Chipp (1921).

${ }^{*}$ Craterium aureum (Schumach.) Rostaf. [5.7]

Locality 13: MC SLS23,712.

New record for Singapore but reported from Thailand by Tran et al. (2006).

Cribraria confusa Nann.-Bremek. \& Y. Yamam. [3.9-5.6]

Locality 1: MC 9909, 9970, 9977, 9978, and 10,010. Locality 2: MC 9918, 9924, and 9925. Locality 3: MC 9976 and 10,013. Locality 4: MC 9938. Locality 5: MC 10,035, 10,036, 10,045, and 10,046. Locality 8: MC 9945 .

First reported from Singapore by Rosing (2009).

Cribraria intricata Schrad.

Locality 1: F 10,005. Locality 3: F 9939. Locality 4: F 10,041. Locality 6: F 9875. Locality 9: F 10,004 and 10,042.

First reported from Singapore by Emoto (1931a).

Cribraria microcarpa (Schrad.) Pers.

Locality 3: F 9952. Locality 5: F 9951. Locality 8: F 10,032.

First reported from Singapore by Rosing (2009).
Cribraria minutissima Schwein. [4.0]

Locality 10: MC 9926.

First reported from Singapore by Rosing (2009) but reported from peninsular Malaysia by Sanderson in a letter to Emoto (1931a).

${ }^{*}$ Cribraria violacea $\operatorname{Rex}[6.9-7.2]$

Locality 1: MC 9929. Locality 8: F 10,032. Locality 10: MC 9950.

New record for Singapore but reported from peninsular Malaysia by Sanderson (1922).

Diachea leucopodia (Bull.) Rostaf.

Locality 6: F 9934.

First reported (as Diachea elegans Fries) from Singapore by Chipp (1921).

Diderma chondrioderma (de Bary \& Rostaf.) G. Lister [5.7]

Locality 11: MC 9948.

First reported from Singapore by Rosing (2009) but also reported (as Diderma arboreum G. Lister \& Petch) from peninsular Malaysia by Sanderson (1922).

Diderma effusum (Schwein.) Morgan [5.7]

Locality 13: MC SLS23,713.

First reported from Singapore by Emoto (1931a).

*Diderma bemisphaericum (Bull.) Hornem. [5.7-6.8]

Locality 1: F 10,024; MC 10,057. Locality 2: MC 9959. Locality 12: F 9958. Locality 13: MC SLS23,692.

Not previously reported in print for Singapore but known from unpublished records of specimens collected by D. R. Reynolds in 1967 (Herbarium BPI). Also reported from peninsular Malaysia by Sanderson (1922) and from Thailand by Tran et al. (2006).

Diderma saundersii (Berk. \& Broome ex Massee) Lado

Locality 10: F 9936.

First reported from Singapore by Rosing (2009). 
*Didymium clavus (Alb. \& Schwein.) Rabenh. Locality 3: F 9877.

New record for Singapore but reported from peninsular Malaysia by Sanderson (1922).

${ }^{*}$ Didymium iridis (Ditmar) Fr.

Locality 1: F 9902 and 9903.

New record for Singapore but reported [as Didymium nigripes var. xanthopus (Ditmar) Lister] from peninsular Malaysia by Emoto (1931a).

*Didymium ovoideum Nann.-Bremek. Locality 3: F 9877 and 9884.

New record for Singapore.

${ }^{*}$ Didymium sp. (Plate I)

Locality 1: F 9897.

One collection was made in the field by W.C.R. and could not be assigned to any described species. Sporocarps were found growing on a dead leaf, evenly distributed and about $1 \mathrm{~mm}$ in total height. The stalks are black and opaque, about half the total height and without lime deposits. Sporothecae are upright, white, globose, and $0.5 \mathrm{~mm}$ in diameter. The peridium is covered with stellate crystals with irregular dehiscence from above. Capillitium is radial, branched but lacks anastomoses, and arises from a pale yellowish brown globose pseudocolumella. Spores are $7-7.5 \mu \mathrm{m}$ in diameter, hyaline, and regularly verruculose with faint clusters of darker warts.

This apparently undescribed species would represent a new record for Singapore. Until additional material is known, we do not consider describing a species new to science as appropriate.

Didymium squamulosum (Alb. \& Schwein.) Fr. [6.7-7.1]

Locality 1: F 10,061. Locality 5: MC 9990. Locality 7: MC 9949. Locality 13: MC SLS23,690.

First reported from Singapore by Emoto (1931a).

${ }^{*}$ Echinostelium apitectum K. D. Whitney [4.0]

Locality 10: MC 9930.

New record for Singapore.
Echinostelium minutum de Bary [4.2-5.5]

Locality 1: MC 9911, 9916, and 10,010.

Locality 2: MC 9940. Locality 5: MC 9931, 9932, 10,008, and 10,037.

First reported from Singapore by Rosing (2009).

${ }^{*}$ Echinostelium paucifilum K. D. Whitney [5.1, 4.5-6.2]

Locality 1: MC 9865. Locality 3: MC 9868. Locality 4: MC 9866. Locality 7: MC 9867.

New record for Singapore.

*Erionema aureum Penz. [= Fuligo aurea (Penz.) Y. Yamam.]

Locality 1: F 9882 and 9883.

New record for Singapore but reported from peninsular Malaysia by Sanderson (1922).

\section{Hemitrichia calyculata (Speg.) M. L. Farr}

Locality 5: F 9987. Locality 12: F 10,020.

First reported from Singapore by Rosing (2009).

${ }^{*}$ Lamproderma scintillans (Berk. \& Broome) Morgan [5.0]

Locality 1: F 9857. Locality 13: MC SLS23,700.

New record for Singapore but reported from Thailand by Tran et al. (2006).

Licea biforis Morgan [5.5-6.8]

Locality 1: MC 10,062. Locality 2: MC 9915 and 9972. Locality 5: MC 10,049.

First reported from Singapore by Rosing (2009).

*Licea bulbosa Nann.-Bremek. \& Y. Yamam. [5.3-6.0]

Locality 1: MC 9873. Locality 3: MC 9874. Locality 9: MC 10,034.

New record for Singapore.

Licea kleistobolus G. W. Martin [4.0-5.5]

Locality 1: MC 9873 and 9980. Locality 2:

MC 9965. Locality 10: MC 10,012.

First reported from Singapore by Rosing (2009). 
Licea operculata (Wingate) G. W. Martin [6.9] Locality 9: MC 9876.

First reported from Singapore by Rosing (2009).

*Licea cf. rufocuprea Nann.-Bremek. \& Y. Yamam. [3.9]

Locality 1: MC 9864.

New record for Singapore.

Lycogala epidendrum (L.) Fr.

Locality 1: F 9998. Locality 7: F 10,029.

First reported from Singapore by Chipp (1921).

* Lycogala exiguum Morgan

Locality 6: F 9921.

New record for Singapore.

Macbrideola decapillata H. C. Gilbert [4.3]

Locality 5: MC 9999 and 10,008.

First reported from Singapore by Rosing (2009).

*Paradiacheopsis solitaria (Nann.-Bremek.)

Nann.-Bremek. [5.9]

Locality 10: MC 9872.

New record for Singapore.

*Perichaena chrysosperma (Curr.) Lister [5.67.7]

Locality 1: MC 9954. Locality 10: MC 9979. Locality 13: MC SLS23,693, SLS23,695.

New record for Singapore but reported from peninsular Malaysia by Sanderson (1922) and from Thailand by Tran et al. (2008).

*Perichaena depressa Lib.[5.5-6.3]

Locality 1: MC 9880. Locality 6: MC 9881. Locality 9: F 10,060. Locality 13: MC SLS23,703.

New record for Singapore but reported from peninsular Malaysia by Sanderson (1922) and Emoto (1931a). Tran et al. (2008) reported this species from Thailand.

*Perichaena dictyonema Rammeloo [6.9]

Locality 13: MC SLS23,698.

New record for Singapore and also reported from Thailand by Ko Ko et al. (2010).
Perichaena vermicularis (Schwein.) Rostaf. [7.0-7.1]

Locality 7: MC 9997. Locality 13: MC SLS23,696.

First reported from Singapore by Emoto (1931a).

Physarella oblonga (Berk. \& M. A. Curtis) Morgan

Locality 1: F 9912 and 10,023. Locality 6: F 9960. Locality 9: F 10,031.

First reported from Singapore by Chipp (1921).

Physarum album (Bull.) Chevall. [4.2-7.2]

Locality 1: F 9920 and 10,059; MC 9985 and 10,009. Locality 5: MC 10,056. Locality 7: MC 10,009. Locality 9: F 9899. Locality 10: MC 9993.

First reported (as Physarum nutans Pers.) from Singapore by Chipp (1921).

*Physarum bogoriense Racib.

Locality 12: F 9922.

Not previously reported in print from Singapore but known from an unpublished record of a specimen collected by D. R. Reynolds in 1967.

Physarum compressum Alb. \& Schwein. [5.36.5]

Locality 1: F 9994. Locality 13: MC SLS23,691, SLS23,697, SLS23,702.

First reported from Singapore by Chipp (1921).

*Physarum cf. decipiens M. A. Curtis

Locality 9: F 9899.

New record for Singapore.

*Physarum flavicomum Berk.

Locality 1: F 9886. Locality 9: F 9888.

New record for Singapore.

*Physarum globuliferum (Bull.) Pers.

Locality 9: F 10026.

New record for Singapore.

*Physarum gyrosum Rostaf. [5.1]

Locality 13: MC SLS23,699. 
New record for Singapore but reported from Thailand by Ko Ko et al. (2010).

*Physarum melleum (Berk. \& Broome) Massee [6.4]

Locality 1: F 10,025; MC 10,034. Locality 4: F 9933. Locality 12: F 10,028.

New record for Singapore but reported from peninsular Malaysia by Sanderson (1922) and Emoto (1931a).

Physarum nucleatum Rex

Locality 12: F 9893 and 10,003.

First reported from Singapore by Chipp (1921).

*Physarum oblatum T. Macbr. [5.3]

Locality 1: F 9889. Locality 4: MC 9890.

New record for Singapore but reported (as Physarum maydis Torr.) from peninsular Malaysia by Sanderson in a letter to Emoto (1931a).

*Physarum penetrale Rex [5.4]

Locality 8: MC 9849.

New record for Singapore.

*Physarum polycephalum Schwein. [6.3]

Locality 1: MC 9870.

New record for Singapore.

Physarum roseum Berk. \& Broome

Locality 1: F 9846.

First reported from Singapore by Emoto (1931a).

*Physarum stellatum (Massee) G. W. Martin

Locality 9: F 9984, 9992, and 10,027.

New record for Singapore.

*Physarum cf. straminipes Lister [5.3]

Locality 13: MC SLS23,701.

New record for Singapore but reported from Thailand by Tran et al. (2008).

\section{Physarum tenerum Rex}

Locality 9: F 10,047. Locality 12: F 9892 and 9893.

First reported from Singapore by Emoto (1931a).
Physarum viride (Bull.) Pers.

Locality 1: F 9891 and 9925. Locality 4: F 10,006. Locality 8: F 9988. Locality 12: F 9989.

First reported from Singapore by Chipp (1921).

Stemonaria longa (Peck) Nann.-Bremek., R. Sharma \& Y. Yamam.

Locality 1: F 9908.

First reported (as Comatricha longa Peck) from Singapore by Chipp (1921).

*Stemonitis axifera (Bull.) T. Macbr.

Locality 1: F 9913 and 9974. Locality 3: F 9859.

New record for Singapore but reported (as Stemonitis ferruginea Ehrenb.) from peninsular Malaysia by Emoto (1931a).

Stemonitis fusca Roth

Locality 1: F 9982 and 10,044. Locality 4: F 9850 and 9901. Locality 9: F 9983. Locality 12: F $10,007$.

First reported from Singapore by Chipp (1921).

Stemonitis splendens Rostaf.

Locality 12: F 9845.

First reported from Singapore by Chipp (1921).

*Stemonitopsis cf. gracilis (G. Lister) Nann.Bremek.

Locality 5: F 9906.

New record for Singapore but reported (as Comatricha pulchella var. gracilis) from peninsular Malaysia by Emoto (1931a).

Stemonitopsis typhina (F. H. Wigg.) Nann.Bremek.

Locality 8: F 10,050. Locality 9: F 9947.

First reported (as Comatricha typhoides

Rost.) from Singapore by Chipp (1921).

*Trichia sp. [4.2] (Plate II)

Locality 5: MC 9871 and 10,064.

Collected by W.C.R., this may be a strange form of a Trichia species distinguished by a capillitium having long spines at intervals. The sporothecae are stalked, up to $1.2 \mathrm{~mm}$ 
total height. Stalks are about half the total height, black, and opaque. The peridium is areolate with about 10 small dark platelets per hemisphere. Capillitium 4-5 $\mu \mathrm{m}$ diam., with short pointed tips and 3 spirals, finely spinulose throughout and with stout spines reaching up to $13 \mu \mathrm{m}$ at irregular intervals, often arranged in groups of 2-5. Spores globose, 9.1-9.3 $\mu \mathrm{m}$ diam., verruculose.

As was the case for the unidentified species of Didymium mentioned earlier in this paper, we do not consider it to be appropriate to describe this as a species new to science until additional material becomes available.

Tubifera microsperma (Berk. \& M. A. Curtis) G. W. Martin

Locality 12: F 9914.

First reported (as Tubifera stipitata Macbr.) from Singapore by Chipp (1921).

\section{DISCUSSION}

Much of Southeast Asia remains underinvestigated for myxomycetes. Twenty-three species are known from Vietnam (van Hooff 2009) and just seven from Myanmar (Reynolds and Alexopoulos 1971). There are no published reports of myxomycetes from Cambodia or Laos.

Some countries within the region have received more attention. Reynolds and Alexopoulos (1971) noted the efforts of many early (1838-1931) investigators on collections from Java, Borneo, and Sumatra (Junghuhn 1838, Moritzi 1845, Cesati 1874, Berkeley and Broome 1876, Penzig 1898, Raciborski 1898, Fischer 1907, Höhnel 1909, Overeem and Overeem 1922, Boedijn 1927a,b, 1928, 1940, Emoto 1931b). More recently, Farr (1990) reported on seven species of myxomycetes collected by Gary Samuels in North Sulawesi, but none of those were new reports for Indonesia. Gilert and Neuendorf (1991) described a new species of Lamproderma [now regarded as a synonym of Elaeomyxa reticulospora (Gilert) G. Moreno, H. Singer \& S. L. Stephenson] from Java. Collectively, these reports bring the total number of species of myxomycetes reported from Indonesia to 119.
Reynolds (1981) published an annotated list of 107 species of myxomycetes from the Philippines based on his personal collections as well as the published and unpublished collections of others. Recent additional records (dela Cruz et al. 2009, Moreno et al. 2009) have raised the total number of species of myxomycetes reported from the Philippines to 129.

Rostrup (1902) was the first to report myxomycetes from Thailand, namely Lycogala epidendrum and Stemonitis fusca. Reynolds and Alexopoulos (1971) listed 42 species from field and moist-chamber collections, including S. fusca. Siwasin and Ing (1982) reported 16 new records, and Ing et al. (1987) reported 17 species, none of which were new to Thailand. Thus, the number of myxomycete species known from Thailand stood at 59 before studies by Tran et al. $(2006,2008)$ and Ko Ko et al. (2010). The recent studies, involving both field and moist-chamber collections, have raised the number of species known from Thailand to 132 .

Eighty-two myxomycete species are known from peninsular Malaysia based on published reports of field collections by Chipp (1921), Sanderson (1922), Emoto (1931a), Lister (1931), and Nawawi (1973). Additional records reported by Rosing (2009) and herein bring the total number of myxomycetes species reported from Singapore to 92. Many of the new records are from moist-chambered bark and litter.

As a result of a series of studies involving most of the country, more than 200 species of myxomycetes have been reported from Costa Rica in the Neotropics (S.L.S., unpubl. data). The ultimate number of species likely to be recorded for Singapore and other nations of Southeast Asia is probably fairly comparable. We hope that the information presented herein will prompt future studies to document more completely the myxomycete biota of Southeast Asia.

\section{ACKNOWLEDGMENTS}

W.C.R. thanks the Singapore Botanic Gardens for the award of a Research Fellowship in 2009. Special appreciation is extended to 
Dr. B. C. Tan, Keeper of the Herbarium, for his generous help and for hosting the stay in Singapore. Thanks also to the Garden's Herbarium Staff, especially Ms. Serena Lee and Mr. Paul Leong, as well as to Dr. Shawn Lum and Mr. Wong Choong Min, who are responsible for the GPS coordinates utilized herein. S.L.S. expresses his appreciation to Sarah Spurrier (now Sarah Roberts) for collecting samples in Singapore and to Sally Edwards for assisting with the processing of those samples.

\section{Literature Cited}

Berkeley, M. J., and E. C. Broome. 1876. Supplement to the enumeration of the fungi of Ceylon and Java. Trans. Linn. Soc. Lond. 15:82-86.

Boedijn, K. B. 1927a. Mycetozoa von Sumatra. Misc. Zool. Sumatr. 17:1-3.

- 1927b. Mycetozoa von Sumatra II. Misc. Zool. Sumatr. 24:1-4.

- 1928. Verzeichnis der von Sumatra bekannten Mycetozoa. Ann. Mycol. 26:450.

- 1940. The Mycetozoa, fungi and lichenes of the Krakatau group. Bull. Jard. Bot. Buitenzorg III 16:358-429.

Cesati, V. 1874. Mycetum in itinere Borneensi. Hedwigia 13:186.

Chipp, T. F. 1921. A list of the fungi of the Malay Peninsula. Gard. Bull. (Singapore) 2:311-417.

Cruz, T. E. E. dela, R. V. Kuhn, A. O. M. Javier, C. M. Parra, and T. H. Quimio. 2009. Status of the myxomycete collection at the UPLB-Museum of Natural History (UPLB-MNH) Mycological Herbarium. Philipp. J. Syst. Bot. 3:97-111.

Emoto, Y. 1931a. The Malayan myxomycetes. J. Bot. 69:38-42.

- 1931b. Javanische myxomyceten. Bull. Jard. Bot. Buitenzorg III 11:161-164.

Farr, M. L. 1990. Pages 169-173 in Samuels et al. Contribution toward a mycobiota of Indonesia. Mem. N.Y. Bot. Gard. 59.

Fischer, E. 1907. Ueber einige von Herrn. Prof. E. Kissling in Sumatra gesammelte Pilze. Mitt. Naturforsch. Ges. Bern 1906:109-123.
Gams, W. 2005. Report of the committee for fungi: 13. Taxon 54:828-830.

Gilbert, H. C., and G. W. Martin. 1933. Myxomycetes found on the bark of living trees. Univ. Iowa Stud. Nat. Hist. 15:3-8.

Gilert, E., and M. Neuendorf. 1991. A new species of Lamproderma (Myxomycetes) found in Java. Nord. J. Bot. 10:661-664.

Höhnel, F. von. 1909. Fragmente zur Mykologie. Javanische Myxomyceten. Sitzungsber. Akad. Wiss. Wien. 118:427-442.

Hooff, J. P. M. van. 2009. Cribraria tecta, a new myxomycete from Vietnam. Bol. Soc. Micol. Madrid 33:129-136.

Ing, B., J. Siwasin, and S. Samarnpan. 1987. Myxomycetes from Thailand II. Mycotaxon 30:197.

International Plant Names Index. 2008. http://www.ipni.org (accessed 16 April 2010).

Junghuhn, F. W. 1838. Praemissa in Floram Cryptogamicam Javae insulae. Fasc. I. Java.

Ko Ko, T. W., T. T. M. Hanh, S. L. Stephenson, D. W. Mitchell, C. Rojas, K. D. Hyde, S. Lumyong, and A. H. Bahkali. 2010. Myxomycetes of Thailand. Sydowia 62: 243-260.

Lado, C. 2005. An on-line nomenclatural information system of Eumycetozoa. http:// www.nomen.eumycetozoa.com (accessed 7 April 2010).

Lado, C., U. Eliasson, S. L. Stephenson, A. Estrada-Torres, and M. Schnittler. 2005. (1688-1691) Proposals to conserve the names Amaurochaete against Lachnobolus, Ceratiomyxa against Famintzinia, Cribraria Pers. against Cribraria (Schrad. ex J.F. Gmel.) and Hemitrichia against Hyporbamma (Mycomycetes). Taxon 54:543545.

Lister, G. 1931. Notes on Malayan Mycetozoa. J. Bot. 69:42-43.

Martin, G. W., and C. J. Alexopoulos. 1969. The myxomycetes. University of Iowa Press, Iowa City.

Mitchell, D. W. 2004. A key to the corticolous myxomycetes. Syst. Geogr. Pl. 74:261285.

Moreno, G., D. W. Mitchell, S. L. Stephenson, and T. E. dela Cruz. 2009. A new 
species of Craterium (myxomycetes) with reticulate spores. Bol. Soc. Micol. Madrid 33:175-180.

Moreno, G., W. C. Rosing, D. W. Mitchell, and S. L. Stephenson. 2007. Comatricha pseudonigra, a new corticolous myxomycete from Australia. Bol. Soc. Micol. Madrid 31:171-175.

Moritzi, A. 1845. Systematisches Verzeichniss der von H. Zollinger in den Jahren 1842-1844 auf Java gesammalten Pflanzen vebst einer kurzen Beschreibung der neuen Gattungenund Arten. Solothurn.

Nawawi, N. 1973. A new species of Licea from Malaysia. Trans. Br. Mycol. Soc. 60:153154.

Overeem de Hass, C., and D. Van Overeem de Hass. 1922. Verzeichnis der in Niederländisch Ost-Indien bis dem jahre 1920 gefundenen Myxomycetes, Fungi und Lichenes. Bull. Jard. Bot. Buitenzorg III 4:38.

Penzig, O. 1898. Die Myxomyceten der Flora von Buitenzorg. Flore de Buitenzorg, II. Brill, Leiden.

Raciborski, M. 1898. Ueber die javanischen Schleimpilze. Hedwigia 37:50-55.

Reynolds, D. R. 1981. Southeast Asian myxomycetes. II. Philippines. Kalikasan 10:127150 .
Reynolds, D. R., and C. J. Alexopoulos. 1971. Southeast Asian myxomycetes. I. Thailand and Burma. Pac. Sci. 25:33-38.

Rosing, W. C. 2009. Corticolous myxomycetes of Singapore. Gard. Bull. (Singapore) 61:151-157.

Rostrup, E. 1902. Flora of Koh Chang: Fungi. Bot. Tidsskr. 24:355.

Sanderson, A. R. 1922. Notes on Malayan mycetozoa. Trans. Br. Mycol. Soc. 7:239256.

Siwasin, J., and B. Ing. 1982. Myxomycetes from Thailand. Nord. J. Bot. 2:369-370.

Stephenson, S. L. 1989. Distribution and ecology of myxomycetes in temperate forests. II. Patterns of occurrence on bark surface of living trees, leaf litter, and dung. Mycologia 81:608-621.

Tran, H. T. M., S. L. Stephenson, K. D. Hyde, and O. Mongkolporn. 2006. Distribution and occurrence of myxomycetes in tropical forests of northern Thailand. Fungal Divers. 22:227-242.

- 2008. Distribution and occurrence of myxomycetes on agricultural ground litter and forest floor litter in Thailand. Mycologia 100:181-190.

Wrigley de Basanta, D. 2004. The effect of simulated acid rain on corticolous myxomycetes. Syst. Geogr. Pl. 74:175-181. 